\title{
A Feminist Scheme Conveyed through Catherine Jemmat's The Rural Lass
}

\author{
Haifa Almufayrij \\ Department of English Language and Literature \\ Faculty of English, College of Arts, King Saud University \\ Riyadh, Kingdom of Saudi Arabia \\ Email: hmofaireeg@KSU.EDU.SA
}

Received: $1 / 24 / 2021$

Accepted: 4/30/2021

Published: 5/24/2021

\begin{abstract}
This study analyses The Rural Lass by Catherine Jemmat (1714-66); the poem will shine a new light on a feminist agenda conveyed through Jemmat's views through the persona of the rural lass by linking the lass' own experience with marriage. Challenges in a patriarchal society among female poets in the early ages and before the twenty-first century deserve appreciation for their contributions to early feminist literature. The author will illustrate how Jemmat negotiated her ambitions despite the cultural restrictions that were placed upon her during the $18^{\text {th }}$ century through a rural persona. Jemmat skillfully creates a light-hearted poem, but also one that reflects the determined voice of a speaker who refuses to allow others to dictate her life. Jemmat seems to achieve this in The Rural Lass, as she subtly challenges the parental and societal objections that could often, as in Jemmat's case, prevent the marriage of a loving couple. This article will study through the feminist literary criticism, that closer analysis of the variations within the metrical composition and of the poetic features in The Rural Lass shows that a deeper level of meaning can be achieved. The structured reasoning ensures that the rural lass appears rational and justly defiant. This paper also explores how a close study of the text allows for the emergence of the admirable spirit of the figure of the rural lass that expresses challenges in a patriarchal society, an eighteenthcentury British feminist that has been criticized by her community.
\end{abstract}

Keywords: $18^{\text {th }}$-century poetry, feminism, Patriarchal Society, poetic features, urban phenomena, The Rural Lass, Catherine Jemmat

Cite as: Almufayrij, H. (2021). A Feminist Scheme Conveyed through Catherine Jemmat's The Rural Lass. Arab World English Journal for Translation \& Literary Studies 5 (2) 62-75. DOI: http://dx.doi.org/10.24093/awejtls/vol5no2.5 


\section{Introduction}

Catherine Jemmat was a memoirist and writer of verse and prose. Jemmat wrote several poems representing her struggles, where she or her subject is mistreated. Through the exploration of Jemmat's struggles and analysis of The Rural Lass, this study will provide new perspectives on eighteenth-century British poetry and patriarchal issues. In other words, Jemmat skillfully used her writings as a means to express challenges in a patriarchal society, especially among females. As Barros and Smith (2000) observe, Eighteenth-century British women, against all odds, began to write, and one of the conflicts they had to negotiate was setting the record straight.

The Rural Lass by Catherine Jemmat was one of the $18^{\text {th }}$-century works and not widely read. Rooted in the social conditions of eighteenth-century Britain, the poem is a compelling social commentary. Catherine Jemmat is presenting herself as a woman mistreated and held back by cultural and financial circumstances and norms. Ellen explains that she was not able to find forgiveness anywhere for just about anything. She flees to her family for support, and they only make things worse, especially her father. Moody (2018) unfolds that her memoir is about a woman seeking a home, unable to find or create one for herself. Jemmat's father, Admiral John Yeo, is the worst of her family to her. At the ripe age of five, Jemmat's mother deceased; her father then sets out to remarry, and does so with a girl shy of nineteen. Faced with the inevitable, this new wife attempts to love her like her own, but the task at hand proved more difficult than intended as she begins to act irrationally towards young Jemmat. Given her father's occupation and tendency to be away from home for several bouts of time, she was sent to study at a boarding school. Though she was not given the chance to indulge in the comforts of love in her upbringing, she did so upon meeting a young surgeon. Unfortunately, he dies before their promises to each other are fulfilled and Jemmat learns she would only like to marry for love; turning down the offer of marriage from a tradesman with significant wealth.

Moody (2018) explains that after battling for a marriage constructed on love, she settles on a silk mercer named Jemmat and has a child with him. Powerful turns of events reveal him to be a cruel man; threatening her with his violence and hurtful accusations of adultery and as a result, Jemmat suffers a miscarriage. Her father refuses to give up the dowry, earning his daughter a life of physical abuse with no remorse towards the monstrosities her husband inflicted. She and her husband's sister begin to fight over power and space. She does "fall" at one point, but she does not tell much of that - instead, we hear about the brawls between her and her sister in law over who will end up at which property. The life Jemmat so desperately craved to escape turned out to be the closest to safety and felicity she ever got.

She struggled but endured to express the voice of an independent woman in her second volume (1762). The following lines from one of her poems are expressive of her thoughts regarding the power of the pen (Moody, 2018, p. 3):

Question, on the Art of Writing

Tell me what genius did the art invent,

The lively image of a voice to paint?

Who first the secret how to colour found, And to give shape to reason, wisely found? 
With bodies how to cloathe ideas taught, And how to draw the pictures of a thought? Who taught the hand to speak, the eye to hear, A silent language roving far and near? Catherine Jemmat (1750-66)

She raises questions to display the multifaceted skills of the talent of the art of writing. Since it is through her mastery of writing in the memoirs, she retells stories of herself and her subjects' mistreatment by a relative. She says because she has been saddened by her own life, she cries over stories in newspapers. One touching Prologue is for a benefit play for a hospital: "With sympathetic warmth to feel the throws, /And racking anguish of another's woes" (Moody, 2018, p. 8). The aesthetics of her verse are centrally 18th century.

Pruitt (2007) supports Jemmat's representation of the mistreatment of rural women in her memoirs. She clarifies that the most common response to the plight of rural women in legal contexts often show little to no empathy or understanding.

\section{Literature Review}

The poetic text chosen in this study requires literary analysis to fathom the feministic tone Jemmat so intricately executed. Through this analysis, we will be able to make use of feminist literary criticism. For the past few decades, there have been many debates regarding the works of Feminist artists. According to Radtke (2017), feminism can be identified in terms of a set of ideas or beliefs rather than the participation of particular political movements. Given the historical context, it is easily deciphered that the works of feminists in the eighteenth-century went under appreciated and understood. This acknowledgement clarifies that commitment to and advocacy for women's rights has not been confined to the Women's Liberation Movement in the West. Thus, feminism can be framed within a broadly liberal approach to social, political, and economic life. Although most feminists would agree that there is an air of precedence surrounding the ongoing fight to achieve equal rights for women, others have argued that it is not a necessary condition for feminism to succeed.

Ahmed (2000) attempted to interpret the true meaning of feminist theory and explains that it proves complicated since the meanings of both theory and feminist are up for debate. In her contribution to explaining this issue, she presents a playful account of somebody doing the counting:

I can almost see a ghostly image of a woman, upstairs in the dusty attics of our institutions, counting out theories, counting out feminisms. ... I can almost hear her voice, gleeful and joyous, as she throws out some works, names them as impostors, saying that they don't count, that they can't be counted. Am I that woman? Have I been her? Are you her? (p. 97)

She continues to explain that the argument is not a fixed object or end product but a process of critique and analysis. 
Brandt and Haugen (1997) explored the significant function of the term 'feminism' as a contested concept, and its historical roots can be traced to as far back as the Enlightenment period. Since it contains theoretical variation, disagreements, and contrasts, it is difficult to give a precise definition of the term feminism without the risk of excluding many of the ideas that have been characterized as feminist. Brandth (2003) supports this discussion and explains that family farm is "hegemonic in agricultural gender research" (p.1). Men are placed as head of the "family farm enterprise; women in the subordinate position of 'farm wives' defined by their dependency, their marriage, and family-related responsibilities" (p.1). Brandth and Haugen (1997) further explain that the analysis of the gendered nature of rurality highlights its validation of the subordination of women and the limits on women's abilities, particularly if the choices challenge perceived gender roles.

Sireni (2015) evaluated patriarchal relations on farms and considered them as the underlying determinant which structures gender division of labor and thus defines women's subsidiary role on family farms. Bharathi (2019) also endorsed this point and explained that these women are discriminated against in their family, in their workplace, as well as in their society. They are dominated and reduced to do only household work after marriage. This is because women's oppression under male domination rarely, if ever, consists solely in depriving women of political and legal rights but also extends into the structure of our society and the content of our culture, the workings of languages, and how they shape perceptions and permeate our consciousness (Bartky, 2017).

Warren-Smith and Monk recognized that during the eighteenth century, the domestic role of women necessitated the need for self-sufficiency in providing for the family, this role extended to managing and working in the dairy yet, as farm sizes increased production, the "farmers' wife lost her productive function" (Verdon, 2003, p. 24). This argument is also explored in Brandth (2002) and inherent in this research in which women working on the farm have not typically been represented as active agents. Verdon explains that they were portrayed as passive victims who cannot shape their roles as the wives and mothers of farm successors.

For this research and to understand the persona of the 'rural lass', it will be necessary to understand the predicament of rural women during this age. Lewis (2020) explains that these values can be revealed through feminist literary critics to reveal these subconscious ideas to show how women have been marginalized in literature.

Feminist literary criticism examines two opposing ideas closely and simultaneously; what the author has chosen to include in the text and what has been left behind. Examining the lack of expression is most telling about not only the writer, but the societal expectations present at each specific time period. The term given to said technique is "hermeneutics of suspicion", and with the aid it provides, literary critics are hopeful it will depict how women are marginalized in the language of literature. According to Lewis (2020) this form of approach to literary criticism assumes that there is an unconscious transference of previously held assumptions to the text through writing, which reveals what society believes. Lewis states that feminist literary critics

Arab World English Journal for Translation \& Literary Studies 
believe that writing is not neutral; instead, it is influenced by the writer's values, who then transfers those values to the text, often unintentionally.

Crossman (2016) exhibits the idea that before feminism, most women artists were invisible to the public eye. They were often denied exhibitions and gallery representation based on the sole fact of their gender. He also explains that Feminist artists sought to create a dialogue between the viewer and the artwork through the inclusion of women's perspective to incite the viewer to question the social and political landscape. Through this questioning, it could possibly affect the world and bring change toward equality.

One particular argument which supports this study is Kamla Bhasins' perspective on feminism. She states that people across the world mistake feminism to be an urban concept. According to them, it is the women of the upper class that can bring about change in society (McAfee, 2018). Bhasin, however, begs to differ and claims that it is incorrect to state that feminism is an urban phenomenon. This claim is supported by the notion that major women's movements throughout history were proposed by rural women. The present paper attempts to study The Rural Lass through a feminist interpretation conveyed through Jemmat's views through the persona of the rural lass and focus on her challenges in a Patriarchal Society.

Matthews and Rader (1973) explain that there are fewer autobiographies by eighteenthcentury British women. He declares, "in the case of women's autobiography, by my count there are fewer than thirty known narratives, not including terse ones, by women born in Britain, though others are undoubtedly hidden in manuscripts in libraries and family archives" (p. 3).

Lonsdale (1990) suggests mysteries are surrounding Catherine Jemmat, but there are about so many women writers. In Virginia Woolf's Memoirs of a Novelist, two of the book's memoirs demonstrate how little we know of women's lives because quite deliberately their relatives and friends will say nothing truthful. Hence, she slips from our grasp only glimpsed in a phrase here or there.

Folkenflik (2016) takes a close look at a generation of feminist scholars, including but not limited to the pioneering Patricia Meyer Spacks, Felicity Nussbaum, Amy Culley, Dianne Dugaw, Cristine Levenduski, and Lynda M. Thompson, have greatly forwarded our understanding of eighteenth-century women's autobiography. She concludes that eighteenth-century autobiographies of both men and women appeared in more significant numbers than in the seventeenth century. The voices of women who would not have written or been published earlier were heard.

The word 'autobiography' itself did not appear in a title until the nineteenth century and was replaced with 'memoirs'. Folkenflik explains that term is too broad, covering autobiography and biography, as well as events recounted from personal knowledge.

After tracing scholarly studies of Jemmat, my contribution will attempt to address a gap in the literature by dealing with an area that is rarely studied and has not been given enough attention. 
One can notice that her poetry does not get much critical attention since Jemmat is remembered as a memoirist. However, she wrote many poems on various issues, and some may have an underlining feminist theme that deserves to be considered in this period. In other words, there is a need for research to illustrate Jemmat's skilfull use of her poetry as a means to fight for equality and women's rights in her society. Hence, the author will present how Jemmat negotiated her ambitions and struggles in the face of the cultural restrictions placed upon her during the $18^{\text {th }}$ century through an analysis of a rural persona in her poem The Rural Lass. This will be done by a more comparative examination of the variations within the metrical composition and of the poetic features in the poem to attempt to argue that a closer examination of the poem displays feministic overtones.

\section{Methodology \\ Findings \\ Analysis}

The data of this study are collected from The Rural Lass (appendix A) by Catherine Jemmat. It is a very powerfully constructed poem; the robust features of the metrical composition, structure, and language within the poem contribute to the creation of a solid independent voice which takes the listener into the mind of a resilient woman of the 18th century. The poem explores the passionate will of a 'rural lass', determined to marry the man of her choice against all opposition. The inspiration seems to be a small minority of young people who began change by basing marriage on love and with a partner of their choice, which was often considered not to be a sound basis for marriage at the time (Stone, 1997). In this poem, which has autobiographical significance, there are echoes of her own-Rural Lass- nature and defiant spirit. Yet, rather than appearing naive, the speaker is portrayed as rational, considering all opposing arguments in the poem. Thus, the poem's structure also means reading a fight, revealing her thoughts and feelings.

The Rural Lass is a monologue of a young country girl written in ballad form; each stanza is a four-line quatrain with a regular alternating rhyme scheme (abab). The ballad form establishes the theme of country-life to frame the innocence of youth through the portrayal of a commonspeaking country girl. The poem's structure displays an argument in process, as the speaker defiantly justifies her decision to marry the husband of her own choice. It highlights a sense of separation between her independent and resilient personality and parental and patriarchal views on women, the expectations her society imposed on women, and how she learned to cope and step forward to marry her beloved Harry. Through the choice of words, she is presenting a case for defending her right and voicing her needs, 'My father and mother, (what ails 'em?)', "Pretend I'm too young to be wed." The word "pretend" negates the idea of being young and thus asserts her mature mind. Stone (1997) states that parents justified their control with religious statements like honoring your father and mother. This was used as a moral justification for parental control over marriage during that time. This clear commandment is not followed by the speaker, who, throughout the poem, seems to have a vital purpose.

The emphasis shifts to defiance against the path she is expected to pursue as a young woman living in a patriarchal society. She challenges her parents:

They expect, but in troth I shall fail 'em, (3) 
Not waiting for parents' consenting (25)

To convey the motive behind challenging her parents' expectations and failing them, she argues that the path her parents expect is one where she is to finish her 'chair's and 'bed', and 'Wooden chairs'. The poet chose to italicize these words in the poem, perhaps highlighting a gap between her and her parents. These items which they render essential, she seems to consider mere wood, materialistic items that don't carry any significance for her. She is pursuing this marriage for love; "The main chance in wedlock is love" (8).

Secondly, the language used in the poem creates the aural impression of a country voice to validate her conviction for choosing to be married for love; Jemmat includes "em" (1) and "e'er" (18). Colloquial expressions which play a role with the use of informal languages, such as 'strapper' (30) and 'nettl'd' (17), "fig for your richest brocading" (57) and, "I value no dainties, a button" (55), Oxford English Dictionary defines 'fig' here as denoting something valueless, or contemptible and similarly 'button' to mean something of minimal value. Such expressions, therefore, allow Jemmat to convey the speaker's complete dismissal of the objections to her planned marriage.

Ultimately, this argument increases in intensity towards her fathers' treatment.

My father, when ask'd if he'd lend us

An horse to the parson to ride;

In a wheel-barrow offer'd to send us,

And John for the footman beside.

His answer to her need for a horse to go to church to marry seems to undermine her worth. He offers her a wheel-barrow. A wheelbarrow is defined as a small hand-propelled vehicle, usually with just one wheel, designed to be pushed and guided by a single person using two handles at the rear, a device used for carrying loads and not people. The father seems to be ridiculing her, which has overtones of Jemmat's harsh treatment and struggles with her father. Oxford Dictionary of National Biography reveals that Catherine's Memoirs portray the tensions between her own romantic experience and the violent father who tried to coerce her into marrying prosperous men.

Throughout the poem, the speaker examines then dismisses objections to her marriage, "And he may prevent us that can." For instance, exclamations are used to capture the disapproval of the neighbors: "Sure never girl acted so madly!"(19). The opening line of the following stanza can then be read as an anapaest followed by an iambic substitution so that the emphasis is placed on her willful determination:

Yet I will be marry'd to-morrow,

And charming young Harry's the man;

My brother's blind nag we can borrow,

And he may prevent us that can.

This is further emphasized by her disregard for anyone's warnings, including her mother, who warns her about the difficulties of raising a child, and Poll, who cautions her that Harry is a

Arab World English Journal for Translation \& Literary Studies 
"rover." She examines and replies to her parent's expectations, "And he may prevent us that can" (24).

Her determined character persists as we see her making her dowry. In the first few stanzas of the poem, we can see a religious lexical field developing: 'troth', wedlock', 'church', 'confest, 'parish', 'Adam', 'Eve' - suggesting her strong faith, which ties together at the end. The speaker even goes so far as to equate her relationship with that of Adam and Eve, who were 'order'd to marry" (68), suggesting that society's unjustified opposition to the marriage of a loving couple defies God's will. This is primarily used to strengthen her case for marrying the husband of her choice, Harry. Moreover, she continues her resilience when she ignores the warning of her friend Poll Barnley. She proves to be decisive and somewhat victorious as she states, "Yet I will be marry'd tomorrow" (21), going on to describe Harry as 'charming'. When giving an example of her brother's disobedience, she states how they now live like a "king and a queen" (28). This tone ensures the validity of her decision and eliminates any thoughts or images which can lead to ideas of seeming immature or unrealistic.

The poem gains ground from the objections of parents, neighbors, and Poll Barnley to then consider potential financial problems in married life. A mature understanding of the reality of her circumstances is demonstrated by the speaker and accompanied by her willingness to endure them: "We can live by the sweat of our brow" (50), she insists, emphasizing her certainty and determination. By coupling possible objections with considered responses, then, Jemmat ensures that the speaker's final decision that "nothing shall tempt me from Harry" (65) appears a reasoned conclusion. Biographies of Catherine Jemmat's life suggest echoes in the poem of her nature and defiant spirit. Wood (2010) describes her as passionately rebellious, with numerous admirers. In her Memoirs, it indicates that she desired to marry 'a Mr. B. of all the admirers that she had, but the courtship did not succeed as her father "forbade it", and eventually Mr. B gave up his suit since he had no money. Catherine finally married on impulse a seemingly wealthy silk mercer, although she stresses that this was 'not for love. One could assume that in the light of the fact that the speaker in the poem professes to love her partner and expects material hardship after marriage, it may describe an imagined alternative ending for her relationship with the poor Mr. B., in which she allows her love to override outside objections. Accordingly, escaping to an ideal situation, where women can develop their identities apart from the suppressive authority of males influence to find freedom of choice in marriage.

Furthermore, Jemmat utilizes the metrical composition to project the identity of the 'rural lass'. The metrical composition of The Rural Lass may seem simple at first, yet the role it plays as a whole demonstrates a mindful use of form and meter to exhibit the reader's response. Moreover, the versification of a poem with the grouping of words and sounds within stanzas to emphasize the metrical rhythm for a poem is a composition dictated and designed to be executed by voice (Ferguson, 2018). In The Rural Lass, the poet employs basic anapaestic trimeter quatrains since the anapaests' rising meter creates a lively rhythm (Overton, 2010). The effect of the meter gives the poem a rising rhythm and a continual forward movement which is appropriate for the excitement of a young lass suddenly falling in love and rushing into a rapid marriage of her choice. 
As Fry (2009) puts it in his book The Ode Less Travelled", anapaests give a "characteristic lilt which is 'rhythmic and fast-moving" (p. 13).

Furthermore, the use of end stops for the second and fourth lines of every stanza on an anapaestic foot, Jemmat ensures that the meter remains insistent. Thus asserting an optimistic frame of mind which asserts that the "cheery" ( 5) rural girl will overcome the hardships that may occur during the marriage. For instance, at the beginning of the poem, the lass states how her parents "pretend I'm too young to be wed" (2). The use of an iambic substitution on the first syllable of 'pretend' highlights her boldness and belief that her parents are wrong to doubt her. This also slows down the poem's pace, further emphasizing that her views differ strongly in comparison to those of her "father and mother" (1). Jemmat also uses different rhyme types in the poem to support the portrayal of the rural lass's defiance. The Rural Lass consists of quatrains with an alternate rhyme scheme. All stanzas are regular quatrains with a constant alternating rhyme scheme. Interestingly, in each stanza, lines one and three end on a lightly stressed rhyming syllable, and lines two and four ends on a heavily stressed rhyming syllable, providing closure for each stanza (Overton, 2010). The heavy stress placed on the monosyllabic rhyme creates a firm, conclusive sound: for example, 'charming young Harry's the man... And he may prevent us that can (22 and 24). In addition, there is regular internal rhyme within singular lines. For example, in lines 7 , the assonance of the "e" sound is repeated in words 'ine' and 'deary'. This helps create a constant light rhythm which is typical of a country ballad. This light rhyme gives the poem a singsong tone to make an appropriate pace for a joyful marriage. This sense of joy appears to confirm her unwavering conviction in her choice to marry. Moreover, the opening line of the following stanza can then be read with emphasis placed on her willful determination:

Yet I will be marry'd to-morrow,

And charming young Harry's the man;

My brother's blind nag we can borrow,

And he may prevent us that can.

In, "Yet I will be marry'd tomorrow" (21). The ' $T$ ' would usually be stressed but due to this form of rhyme, 'I will' becomes stressed, enabling the writer to get across the defiant tone of the rebellious lass. Furthermore, Jemmat uses an AAAA rhyme-scheme pattern in the eleventh stanza. The end of each line rhyme with one another:

But all that are like her, or wou'd be,

May learn from my Harry and me,

If maids wou'd be maids while they shou'd be,

How faithful their sweet-hearts wou'd be.

This rhyming pattern creates emphasis on this stanza. This particular stanza is inherent to the meaning of the poem since it reaffirms the whole message of the poem along with the rebelliousness and resolve of the lass. The narrator of the poem, the lass, explains that people 'may learn from Harry and me' and that women should have 'sweet hearts' like hers (lines 42 and 44). This reminds us that this is rural lass setting new modes of thought for choosing a partner

Arab World English Journal for Translation \& Literary Studies 
for marriage in a rural community. Hence, the rhythm seems to create a song that celebrates the narrator's forthcoming marriage, regardless of its consequences.

Jemmat's use of caesuras helps highlight messages by eliminating the poem's regularity while providing both dramatic and essential breaks in the line to draw our attention to keywords. The Norton Anthology of poetry defines a ' caesura' as crucial in creating a pause to distinguish the two parts of the line so we can address the second part separately. One example is

Not waiting for parents' consenting,

My brother took Nell of the green;

Yet both far enough from repenting,

Now live like a king and a queen.

"Yet, both far enough from repenting" (27); in this example the caesura is used to back up the girl in the poem's choice of marrying young and "He courted her once he confest" (38) other people have done it and they "now live like a king and a queen" (28), with the italics as extra emphasis. Another example is the line (51) 'of stick a hog, once a year, for fat bacon' encourages the reader to slow down to reflect on the style of life she expects to live with her Harry. I think the caesura is cleverly placed here to pause and create the impression of natural speech so we can recognize that she chose to live a simple rural life with its simple pleasures with her beloved husband.

Moreover, in line three, 'They expect, but in troth I shall fail 'em,' the caesura is used here to divert away from what her parents' expectations are and simply stating that she will fail them. This creates a blunt tone denoting the speaker's strong state of mind as she follows her judgments for marriage. Most of the lines in the poem, however, are end-stopped, keeping a strict syntactical structure, reflecting the rural lass' controlled decisive tone.

Further analysis of the language demonstrates the use of exclamatory marks in the fourth and fifth stanza to highlight the theme of the fearless attitude in the poem, 'Sure girl never acted so madly!'(19). This refers to her choice to marry for love and not based on the standards of her time. The exclamatory mark is also used to vent on her father's reaction to her choice of marriage after he ridicules her, Wou'd we never had ask'd him; for, whip it!(13).

Then, Jemmat employs figurative language to illustrate a vivid description of her relationship with Harry. Jemmat uses a simile to state that the rural lass believes 'his heart is as true as the sun' (66), which indicates her love for Harry. She specifically chose to compare her spouse to the sun, which is 'the central body of the solar system, to imply that her life now revolves around him. This allows Jemmat to convey the speaker's firm belief that the love she shares with her Harry will raise them above a materialistic lifestyle, proving to both the reader and her family that she has made the right choice in marrying him. Moreover, Jemmat uses another simile with a religious connotation to compare her relationship with Harry to Adam and Eve. Jemmat seems to be making comparisons between Eve tempting Adam to eat the dangerous fruit and the lass' belief that 'nothing shall tempt me from Harry" (65). ). Here, the lass is being equated with Eve and has the power to lure Harry into this marriage. Additionally, Jemmat uses a simile describing how her 
brother and his wife "live like a king and a queen" (28) after their rebellious marriage to emphasize the theme of solid will for choosing a partner in a rural community.

Hence, Jemmat illustrates through a rural persona in her poem The Rural Lass her ambitions and struggles during the $18^{\text {th }}$ century. This poem delved into the individuality of the primary persona to display her mind, spirit, eagerness, and passion in the face of the cultural restrictions and breaking away from oppressive patriarchal ideas. This was presented through a clever articulation of variations within the metrical composition and the poetic features in the poem, which voice the rise of individuality to project feministic connotations of an independent intelligent persona.

\section{Conclusion}

In conclusion, Jemmat's The Rural Lass is a powerful poem that reflects the impression of a young rural girl with an unwavering voice who has decided to marry for love. The poem also discusses and presents Jemmat's views through the persona of the rural lass, by linking the lass's own experiences with marriage to her own, which adds an interesting contextual element to the poem. Thus, the reader can identify with the figure criticized by her parents and society and to encourage admiration of her spirit and resolve concerning love and marriage. Overall, the poem's features, choice of words, structure, metrical composition, and language within the poem provide feministic undertones with liberating language that expresses empowerment of a rural girl in expressing herself empathetically. Through the persona of the rural lass, it seems that Jemmat is presenting a persona that can represent an early feminist voice embedded in a patriarchal society.

\section{About the Author:}

Dr. Haifa Almufayrij is an Assistant Professor in the English Department at King Saud University. Her PhD is in English Literature from Loughborough University, United Kingdom (2017) and her current research interests focus on poetry and pedagogy. ORCiD ID https://orcid.org/0000-00024844-1994

\section{References}

Ahmed, S. (2000). Whose counting? Feminist Theory, 1, 97-103.

Barros, C. A., \& Smith, J. M. (2000). Life-writings by British women, 1660-1815: An anthology. Boston: Northeastern University.

Bharathi, N. (2019). Suffering of Women in the Poems of K. V. Dominic. Language in India, vol.19(9),68-73. Available at EBSCOhost, search.ebscohost.com/login.aspx?direct=true \&db=ufh\&AN=138791168\&site=eds-live.

Brandth, Berit. (2003). Gender Identity in European Family Farming: A Literature Review. Sociologia Ruralis. 42. 181 - 200.

Brandth, B., \& Haugen, M. (1997). Rural Women, Feminism and the Politics of Identity. Sociologia Ruralis, 37, 325 - 344.

Crossman, K. A. (2016). Feminist Perspectives on Wife Abuse. Journal of Family Theory \& Review, 8, 2, 253-257.

Ferguson, M. W. (2018). The Norton anthology of poetry $\left(5^{\text {th }}\right.$ ed.) New York W. W. Norton \& Company. 
Folkenflik, R. (2016). 'Written by Herself': British women's autobiography in the eighteenth century. In A. Smyth (Ed.), A History of English Autobiography (pp. 119-132). Cambridge: Cambridge University Press.

Fry, S. (2009). The ode less travelled: Unlocking the poet within. Toronto: CNIB.

Jemmat, C. (1762). The Memoirs of Mrs. Catherine Jemmat, Daughter of the Late Admiral Yeo, Of Plymouth, Written By Herself. Literature Online - English Poetry. London: Printed by Subscription, for Mrs. Jemmat, at Mr. Walker's.

Lewis,J. (2020). What Is the Feminist Approach to Literary Criticism?. penandthepad.com. Retrieved from https://penandthepad.com/feminist-approach-literary-criticism5819656.html

Lonsdale, R. (1990). Eighteenth century women poets: An Oxford anthology. Oxford: Oxford University Press.

Mann, S. A., \& Patterson, A. S. (2016). Reading feminist theory: From modernity to postmodernity. Oxford: Oxford University Press.

Matthews, W., \& Rader, R. W. (1973). Autobiography, biography, and the novel: Papers read at a Clark Library seminar, May 13, 1972. Los Angeles: William Andrews Clark Memorial Library, University of California.

McAfee,N.(2018).Feminis-Philosophy. Available

at<https://plato.stanford.edu/archives/fall2018/entries/feminist-philosophy/>.

Moody, E. (2018). Foremother memoirist and poet: Catherine Jemmat (f. 1750-60). Retrieved from https://reveriesunderthesignofausten.wordpress.com/

Overton, B. (2010). The Rural Lass: Introduction to Poetry. Loughborough University

Pruitt, L. R. (2007). Toward a Feminist Theory of the Rural. Utah Law Review, 2 (89), 421-488. Available at SSRN: https://ssrn.com/abstract $=933352$

Radtke, L. H. (2017). Feminist theory in Feminism and Psychology [Part I]: Dealing with differences and negotiating the biological. Feminism and Psychology, 27(3), 357 377. https://doi.org/10.1177/0959353517714594

Sireni, M. (2015). Reinventing rural femininities in the post-productivist Finnish countryside. European Countryside, 7(1), 42-56.

Stone, L. (1977). The family, sex and marriage in England 1500-1800. New York: Harper \& Row. Oxford English dictionary. (2000). Oxford: Oxford University Press.

Susan S. L. (1991). Feminist Literary Criticism: How Feminist? How Literary? How Critical?”; NWSA Journal, vol.3(1),3-19.

Verdon, N. (2003). ' Subjects deserving of the highest praise': Farmers' wives and the farm economy in England, c. 1700-1850. Agricultural History Review, 51(1), 23-39.

Wood, J. (2019). 'Catherine Jemmat', An Annotated Digital Miscellany of Eighteenth-Century Poems. Available at https://poeticalscavenger.sfsuenglishdh.net/poems/catherine-jemmatthe-rural-lass/ 


\section{Appendices \\ Appendix A \\ Catherine Jemmat's poem}

"The Rural Lass"

My father and mother, (what ails 'em?)

Pretend I'm too young to be wed;

They expect, but in troth I shall fail 'em,

That I finish my chairs and my bed.

Provided our minds are but cheery,

Wooden chairs wonnot argue a glove,

Any bed will hold me and my deary,

The main chance in wedlock is love.

My father, when ask'd if he'd lend us

An horse to the parson to ride;

In a wheel-barrow offer'd to send us,

And John for the footman beside.

Wou'd we never had ask'd him; for, whip it!

To the church tho' two miles and a half,

Twice as far 'twere a pleasure to trip it;

But then how the people would laugh!

The neighbours are nettl'd most sadly,

'Was e'er such a forward bold thing?

'Sure girl never acted so madly!'

Thro' the parish these backbitings ring.

Yet I will be marry'd to-morrow,

And charming young Harry's the man;

My brother's blind nag we can borrow,

And he may prevent us that can.

Not waiting for parents' consenting,

My brother took Nell of the green;

Yet both far enough from repenting,

Now live like a king and a queen.

Pray when will your gay things of London

Produce such a strapper as Nell's?

There wives by their husbands are undone,

As Saturday's news-paper tells.

Poll Barnley said, over and over,

I soon shou'd be left in the lurch;

For Harry, she knew, was a rover,

And never wou'd venture to church.

And I know the sorrows that wound her,

He courted her once, he confest; 
With another too great, when he found her, He bid her take him she lik'd best.

But all that are like her, or wou'd be,

May learn from my Harry and me,

If maids wou'd be maids while they shou'd be,

How faithful their sweet-hearts wou'd be.

My mother says, clothing and feeding

Will soon make me sick of a brat:

But, tho' I prove sick in my breeding,

I care not a farthing for that.

For if I'm not hugely mistaken,

We can live by the sweat of our brow;

Stick a hog once a year, for fat bacon,

And all the year round keep a cow.

I value no dainties a button,

Course food with our stomachs allay;

If we cannot get veal, beef, and mutton,

A chine and a pudding we may.

A fig for your richest brocading;

In lindsey there's nothing that's base;

Your finery soon sets a fading,

My dowlass will last beyond lace.

60

I envy not wealth to the miser,

Nor wou'd I be plagu'd with his store:

To eat all and wear all is wiser;

Enough must be better than more.

So nothing shall tempt me from Harry,

His heart is as true as the sun:

Eve with Adam was order'd to marry;

This world it should end as begun. 